\title{
FOOD RELOCATION AND THE NESTING BEHAVIOR IN SCARABAEUS AND KHEPER (COLEOPTERA: SCARABAEINAE)
}

\author{
Gonzalo Halffter, Violeta Halffter \& Mario E. Favila \\ Instituto de Ecología, A.C., Carretera Antigua a Coatepec No. 351, El Haya, 91070, Xalapa, México. \\ <gonzalo.halffter@inecol.edu.mx>
}

Halffter, G., V. Halffter \& M. E. Favila. 2011. Relocalización de alimento y comportamiento de nidificación en Scarabaeus y Kheper (Coleoptera: Scarabaeinae). Acta Zoológica Mexicana (n. s.), 27(2): 305-324.

RESUMEN. En los últimos años se ha avanzado mucho en el conocimiento de las relaciones intersexuales y los comportamientos de nidificación de Scarabaeus Linnaeus y Kheper Janseen. En este trabajo, utilizando toda la literatura publicada, aunada a observaciones inéditas, se analizan en detalle las interacciones intrasexuales e intersexuales durante los periodos de alimentación, cópula y nidificación en ambos géneros. En conjunto quedan definidos dos tipos de comportamientos: 1) El que hemos llamado tipo sacer cuyos rasgos más característicos son la ofrenda por el macho de una bola prenupcial que la hembra consume, pero no utiliza para la nidificación; más tarde, con el ovario ya maduro, la hembra puede nidificar sola sin nuevas cópulas ni apoyo del macho. 2) El que se presenta en numerosas especies africanas de Scarabaeus y Kheper, en las que la hembra copula con distintos machos, pero una vez desarrollado el ovario el proceso de nidificación es una actividad conjunta entre un macho y la hembra, fabricando la hembra con la bola rodada y enterada una o varias bolas-nido que reciben cuidados postoviposición. Aunque la casi totalidad de las hembras que nidifican almacenan en su espermateca espermatozoides de cópulas anteriores con otros machos, la permanencia del último macho durante el proceso de nidificación parece estar asociada a un incremento de su paternidad, al ser el último macho en copular con la hembra y evitar la intromisión de otros machos.

Palabras clave: Comportamiento del apareamiento y nidificación, competencia espermática, Scarabaeus, Kheper, escarabajos del estiércol, Scarabaeinae.

Halffter, G., V. Halffter \& M. E. Favila. 2011. Food relocation and the nesting behavior in Scarabaeus and Kheper (Coleoptera: Scarabaeinae). Acta Zoológica Mexicana (n. s.), 27(2): 305-324.

ABSTRACT. In recent years much has been learned about the intrasexual relationships and nesting behavior of Scarabaeus Linnaeus and Kheper Janseen. In this study, based on the published literature, as well as our unpublished observations, the intra- and intersexual relationships during periods of feeding, copulation and nesting are analyzed in detail for both genera. We define two types of behavior: 1) One that we refer to as the sacer type, the most characteristic traits of which are the male offering the female a prenuptial ball of dung which she consumes but does not use for nesting; later when the ovary is mature

Recibido: 19/03/2010; aceptado: 17/01/2011. 
the female can nest alone without copulating again and without the support of the male. 2) That which occurs in several African species of Scarabaeus and Kheper where the female copulates with different males, but once the ovary is developed nesting is a joint activity carried out by the male and female; the female making one or several brood balls from the rolled and buried dung ball and all of the brood balls receiving postoviposition care. Although almost all nesting females store sperm from previous copulations in their spermathecae, the presence of the last male mate during nesting appears to be associated with an increase in his paternity as he is the last male to have copulated with the female and prevents the intrusion of other males.

Keywords: Mating behavior, nesting behavior, sperm competition, Scarabaeus, Kheper, dung beetles, Scarabaeinae.

\section{INTRODUCTION}

Dung roller beetles (several tribes of Scarabaeinae), differ from other dung beetles because they cut and transport a ball of food over a distance of several centimeters to several meters. The ball may be cut and rolled by a single individual of either sex, or by a sexually mature pair that uses the ball for nesting (Halffter \& Matthews 1966; Halffter \& Edmonds 1982). During the reproductive period, males invest a considerable amount of time and energy in searching for food, cutting it, and rolling the ball to the nest site. Also, males will fight over a ball and over a female, suggesting a substantial male parental investment. In contrast, the females of most species have a passive role during these activities, and are transported on the ball to the nest by the male, although these females are frequently mated with by other males (Edwards \& Aschenborn 1988, Favila \& Díaz 1996, Halffter 1997, Favila et al. 2005). Female care of the offspring has been observed for some species of this insect group (Halffter \& Edmonds 1982, Halffter 1997). Therefore, the behavior of male and female dung roller beetles can be analyzed in terms of reproductive investment.

Feeding and reproductive behavior in Scarabaeus and Kheper, two genera that are phylogenetically close, have been studied for many years. The processes of horizontal food relocation (making, rolling and burying the ball of dung) and nesting in Scarabaeus, as well as the role played by the males in both processes were described in detail for Scarabaeus sacer Linnaeus thanks to the pioneering work of J.H. Fabre (1897), Heymons \& von Lengerken (1929) as well as the review by von Lengerken (1951), which included observations on $S$. semipunctatus Fabricius, S. laticollis Linnaeus and S. variolosus Fabricius. Right up to the 1970 s it was thought, explicitly or implicitly, that the behaviors described by these authors applied to Scarabaeus and close genera. However, the information that has been gathered in more recent studies of numerous African species paints a more complete picture of the complexity and the factors involved in the processes of nesting in this genus and in the close genus, Kheper.

In many of the African species of Scarabaeus and Kheper the female has been found to stay in the nest (which has one or several brood balls) over a long period of time after oviposition, generally until the emergence of the progeny (see Halffter 
1997). On the other hand, the type and degree of activity of the male varies widely among the species studied. Mating effort (defined as the cost of finding and mating with females to the male) and paternal effort, which increases offspring survival at the expense of the male's reproductive success (Trivers 1972) can be quite different. The behavior of the male and the male-female relationships are, together with the presence or absence of brood care, the elements that introduce differences in the reproductive processes of the species in both genera. In only one of the subgenera of Scarabaeus: Pachysoma MacLeay, endemic to the deserts in southwestern Africa, brood balls are not made; a completely exceptional behavior in a Scarabaeinae, a group in which using the food ball, the female elaborates one or more brood balls or brood masses in which she will lay her eggs (for lack of nesting in Scarabaeinae see López-Alarcón et al. 2009; for the behavior of Scarabaeus (Pachysoma) see Scholtz 1989; Harrison et al. 2003: Scholtz et al. 2004).

In spite of the number of studies published over the last thirty years, since Halffter $\&$ Matthews (1966) no attempt has been made to carry out a comparative study of the similarities and differences in the processes mentioned above among the species of Scarabaeus and Kheper. Nor has there been an analysis of how the different ecological conditions in which Scarabaeus and Kheper live influence their behavior. These conditions can be summarized with two scenarios: 1) Deserts and sandy formations where medium-sized and large mammal dung is very rare; 2) Savannas and other types of herbaceous-shrubby formations where the dung of medium-sized and large mammals is very abundant, but where the intra- and interspecific competition between Scarabaeinae rollers and tunnelers may occur.

This study represents a comprehensive analysis of all the information published to date on Scarabaeus and Kheper, including unpublished observations on Scarabaeus acuticollis (Motschoulsky) in Repetec, Turkmenistan, made by two of the authors (G. $\& \mathrm{~V}$. Halffter). The study focuses on the relative contributions of the male and female in the processes of food relocation and nesting, as well as on the conflicts between the different behaviors of the male in different species and under different ecological scenarios. The study is divided into three parts. In the first we present a synthesis of the behavior of Scarabaeus sacer, the species that provided the basis for understanding the behavior of other species in Scarabaeus and Kheper. In the second part we give a synthesis of the rolling, feeding and mating behavior observed in Scarabaeus acuticollis in the Repetec Desert. Finally, in the third part we give a comparative analysis including the ecological context for the species of Scarabaeus and Kheper in which feeding and reproductive behavior has been studied.

\section{MATERIALS AND METHODS}

This synthesis of the behavior of Scarabaeus sacer has been prepared based on Fabre (1897), Heymons \& von Lengerken (1929), and von Lengerken (1951). For the com- 
parative analysis with other species of Scarabaeus and Kheper a literature search was done using the Expanded Science Citation Index and the following keywords: Scarabaeinae, dung beetle, Scarabaeus, Kheper, nesting behavior, for the years 19922009. In addition, we sought out the publications cited by these studies that were not retrieved by the keyword search, resulting in an additional 19 publications. Some authors do not clearly distinguish between what occurs during the period of feedinggonad maturation that follows the emergence of the adults and what occurs during the nesting period. In both periods food balls are made and rolled, but the participation of the male and female is very different. In order to avoid confusion, our analysis is done in three parts: 1) Behavior during the period of feeding-maturation; 2) Behavior during the nesting process; and 3) Mating.

As regards the behaviors examined in this study, in the third section we make a broad comparison with what occurs in another dung roller beetle Canthon cyanellus cyanellus LeConte. Although this beetle belongs to another tribe of Scarabaeinae: Canthonini, different from that of Scarabaeus and Kheper (Scarabaeini), the processes of rolling, nesting, parental care and the behavior of the male (Favila 2001) are highly comparable. The behavior of $C$. c. cyanellus is attractive in this context for two main reasons. Thanks to more than twenty years of studies by one of the authors (M.E. Favila and his research team), it is the roller beetle for which we have the most information about reproductive behavior, including careful laboratory studies. Furthermore, it is the only Scarabaeinae for which visible genetic markers have been found (Favila et al. 2000, 2004), a discovery that has made it simple to follow and evaluate conflicts between males, and between males and females.

The species included in the analysis and the sources of information are given below. Information on all of the behaviors included was not available for all of the species. The differences depend on whether the observations were made exclusively during the feeding-maturation period, during the nesting period or across both. The species of Scarabaeus and Kheper have been grouped according to the ecological scenarios in which they live.

1) Desert or semi-psammophile species, with limited dung availability: Scarabaeus acuticollis (Motschoulsky) - G. \& V. Halffter, unpublished data; S. sacer Linnaeus- Fabre 1897; Heymons \& von Lengerken,1929; von Lengerken 1951; S. semipunctatus Fabricius - Goggio 1926.

2) Species that are widely distributed in non-arboreal biomes in Western Europe: S. laticollis Linnaeus- Fabre 1925.

3) Species of the savanna and similar landscapes where the dung of different mammals is widely available: Scarabaeus bohemani (Harold) - Tribe 1976; S. catenatus (Gerstaecker) - Sato 1997, 1998; S. funebris (Boheman) - Halffter 1997; S. galenus (Westwood) - Halffter 1997; S. rugosus (Hausmann) - Tribe 1976; Kheper aegyptiorum (Latreille) - Heinrich \& Bartholomew 
1979; Sato \& Imamori 1986, 1988; K. aeratus (Gerstaecker) - Palestrini et al. 1992; K. clericus (Boheman) - Halffter 1997; K. cupreus (Laporte) - Halffter 1997; K. lamarcki (Mac Leay) - Tribe 1976; Halffter 1997; K. nigroaeneus (Boheman) - Tribe 1976; Edwards 1988; Edwards \& Aschenborn 1988, 1989; K. platynotus (Bates) - Sato \& Imamori 1986, 1987, 1988; Sato \& Hiramatsu 1993; Halffter 1997; K. subaeneus (Harold) - Tribe 1976; Halffter 1997.

Field Work. The behavior of Scarabaeus acuticollis (Motschoulsky) was observed by G. and V. Halffter over six days at the end of April in 1978, in the Repetec Biology Station, in the Karakum Desert, Turkmenistan.

The landscape is comprised of sand dunes, mostly mobile, with very sparse vegetation mostly Calligonum sp. shrubs, trees, and in the swales where humidity is higher, the shrubs Haloxylon persicum, Ephedra strobillata, Ammodendron sp., and Tamarix sp. are common, along with the ephemeral grass Carex physodes. The climate is extreme. Although the mean annual temperature is $16{ }^{\circ} \mathrm{C}$, it ranges between a minimum of $-30{ }^{\circ} \mathrm{C}$ (between-year average is $-20{ }^{\circ} \mathrm{C}$ ) and a maximum of $50{ }^{\circ} \mathrm{C}$. Rainfall is 80 to $600 \mathrm{~mm}$ (unusual) per year, with an average of $150 \mathrm{~mm}$.

Observations were made at the beginning of spring, and coincided with rainfall that kept the sand damp to a shallow depth. Over six consecutive days two dromedaries were tethered to a fixed location for several hours in the morning. The exceptional quantity of dung produced attracted many $S$. acuticollis beetles (the only Scarabaeinae collected), and allowed for the observation of 20 to 30 individuals, alone and with mates, per day. Behavior was observed daily from $0900 \mathrm{~h}$ to $1800 \mathrm{~h}$. From the site where the dromedaries were tethered, and therefore the site of the food source for the beetles, these processes were followed: food ball formation, rolling and burying for 40 beetles that rolled alone or with a mate. The site where the beetles and their ball had been buried was marked with a numbered bar and checked $24 \mathrm{~h}$ later. All of the marked beetles were dissected to determine their sex and stage of gonad development. An additional 50 specimens were dissected at different periods during ball rolling to be able to relate the behavior to the sex of each specimen. Four male-female pairs were collected in the field with their corresponding food ball and transported to the laboratory of the Biological Station. Each pair was put into a terrarium $(40 \times 30$ $\times 14 \mathrm{~cm}$ filled halfway with damp sand from the area). Under these conditions, it was possible to observe four pairs mating, and another three mating pairs were observed directly in field.

These ad libitum field observations provide an overview of the different behaviors of $S$. acuticollis during the period of feeding-gonad maturation. Dissection of the females during this period confirmed that the ovariole was immature and the vitellarium had no developed oocytes or that the development of the latter was only incipient. 


\section{RESULTS}

\section{Ethogram of Scarabaeus (Scarabaeus) sacer}

Behavior during the feeding-maturation period. The adults emerge at the beginning of spring. Both sexes, but particularly the female, need a period of feeding that allows the gonads to mature. The beetles fly to a food source and land nearby. The male or the female prepares a ball in the food source following two different behaviors: if the dung is from a sheep or similar animal, the beetle uses its middle or hind legs to roll one or several pellets, while it pulls other dung pellets or fragments towards itself using its front legs, all of which are incorporated into the ball it is making. If the dung is from a cow pat, the beetle uses its clypeus and forelegs to cut away a piece of dung which it pushes under its body. When competition is strong owing to the number of beetles at the food source, the beetles may roll smaller balls or even fragments of dung as they are, without touching them up.

During this period, males and females may roll balls individually, but it is more common for them to do so as a couple. In individual rolling, the beetle goes behind the ball with its head down and its forelegs supported on the ground, while its middle and hind legs grasp the ball, although the middle legs occasionally touch the ground; this is the pushing position. When the male-female pair rolls the ball, the male adopts the pushing position while on the other side of the ball the female takes up the pulling position by placing her middle and hind legs on the ground and pulling the ball with her forelegs. The most common behavior of the female is to walk, following the male as he rolls the ball, at a distance no greater than $3 \mathrm{~cm}$. The most active role in the pair rolling is that of the male who initiates and carries out the preparation of the ball, rolls it from the pushing position and buries it. During this period the ball, rolled and buried by the pair, is eaten by them, but mainly by the female. This is why these balls are thought to be prenuptial offerings made by the male to the female. After burying the ball, mating occurs, and can also be observed on the surface. After mating the male goes to the surface in search of another female. The female remains with the ball until she has eaten all of it.

During the feeding-maturation period fights during rolling are common between beetles of the same sex. The aggressor tries to drive off the owner of the ball and take his place rolling the ball with the female. When the female is rolling the ball alone and encounters other females, they will fight and the winner keeps the ball. When she encounters a male, after making contact, the male takes over rolling the ball and the female follows him. The same process occurs when the males are rolling a ball alone, with respect to other males or females. During a fight the opponents are face to face and they strike each other with their anterior tibia. The owner of the ball tries to drive off the aggressor which tries to climb up onto the ball. 
Behavior during the nesting process. After the feeding period (three to four weeks), with the ovary now mature, the females begin to roll the balls that will be used for nesting, referred to here as brood balls. These balls are made, rolled and buried individually by the female. Once buried, the ball is transformed by the female into an ovoid shape. She then builds a chamber for the egg and oviposits in it. The ball and the egg chamber have an external covering of soil applied by the mother. Once the egg has been laid, the chamber with the egg is sealed and the female abandons the nest.

\section{Ethogram for Scarabaeus (S.) acuticollis}

Behavior during the period of feeding-maturation Scarabaeus acuticollis approach their food source in rapid flight, and land a short distance away from the dung. Activity was observed between 0900 and 1800 h, with a peak between 1000 and $1200 \mathrm{~h}$.

After the first day of observations, close to where the dromedaries were producing their dung, there were between 20 and 30 beetles doing the following: a) flying to the food source ( $10 \%$ of the total number of beetles), b) moving quickly over the sand a certain distance away from the dromedary dung pats, without going directly toward them, searching for balls that had been buried by other beetles (40\%); c) separating dung from the pats and making balls (10\%); d) rolling rough pieces of dung (40\%). Both males and females participated in these activities, but as the observation days passed the proportion of males increased until they were three times more abundant than the females. Dissection of the beetles collected showed that the intestine of those engaging in activities " $a$ " and " $b$ " was empty, while the intestine of those engaged in "c" and "d" were full. This shows that the beetles consume the dung as soon as they take possession of it.

Individual rolling. Individual and paired rolling were observed at the same time (10 to 15 per day, approximately 72 observations in 6 days). In $90 \%$ of the cases, individual rolling was done by a female. Individual rolling is a prelude to rolling by the pair, and may also be done by the male; after which the food balls are buried and then eaten. In general, during individual rolling, the dung fragment was irregular in shape, simply separated from the dung pat by the beetle, without any prior manipulation to give it a more spherical shape.

Unless attacked by a conspecific, the beetle separates and forms a food ball on the top of the dung pile. The beetle holds on to the dung with its middle and hind legs and uses its forelegs to pull together pieces of dung from the pat, or from other nearby dung pats if they aren't very big. Rolling is done from the pushing position, supporting the forelegs on the ground and with the middle and hind legs on the ball. Individuals roll the balls from 50 to $85 \mathrm{~m}$, and do so very quickly. The initial and middle stage of burying the ball is also quick, taking from 30 to 45 minutes. Indivi- 
dual rolling was followed by burying the ball in an oblique, shallow gallery. For the beetles that were not sacrificed that had rolled and buried their food, it was observed that two to three days after burying the food ball, they had eaten all of it and returned to the surface.

Fights and food ball theft. During the separation and individual rolling of the ball, there are frequent attempts by aggressors to appropriate the ball. When the intruder is the same sex as the owner of the ball, the encounter results in a fight. Combat occurs with the two opponents face to face, striking each other with the clypeus and anterior tibia. With the clypeus, one of the contestants makes a quick upwards movement, making a lever with which it could throw its opponent several $\mathrm{cm}$ away, although the latter usually returns to continue the fight. Under the conditions found at Repetec, with many beetles and numerous balls buried in a radius of $100 \mathrm{~m}$, it was possible to observe the robbery of food balls by individuals that were walking along the surface of the sand, but did not approach the dung piles of the dromedaries. These were searching for the small mounds of loose sand that marked where a ball had been previously buried by another beetle. On arriving at one of these mounds the beetle digs into the sand and, depending on the sex of the intruder and that of the owner, the intruder is accepted or violently fended off. When a ball has been rolled and buried by a pair, if the intruder is male he is violently fought off by the male owner; if the intruder is female no external signs of activity are observed and only in a single case were two females found, one on the ball and another nearby.

Ball rolling by the pair. When the formation and rolling of the food ball were started by a male, he violently rejects other males but accepts a female and paired rolling begins. The female joins the male at one of two different moments: a) during the process of separating and preparing the ball, when she participates in cutting and shaping the ball; or b) when the male starts to roll the food ball, or while he is rolling it. During paired rolling, the male assumes the pushing position and the female hangs firmly onto one side of the ball, spinning in circles as it rolls (a position similar to that of Canthon humectus (Say), see Halffter \& Matthews, 1966). The food ball rolled by the pair tends to be spherical but very irregular, with average dimensions of 45 $\times 42 \times 37 \mathrm{~mm}$. The distances that the ball is rolled prior to being buried vary from 10 to $85 \mathrm{~m}$; and the time spent rolling the balls is 3 to 43 minutes $(X=18, n=20)$. Rolling ended when the ball was buried by the male with the female hanging on to it. Thus, the separation and shaping of the ball are mainly done by the male, but rolling and burying the ball are done exclusively by the male, and during both behaviors the female is passive.

Burying the food ball. To bury the ball the male excavates a very shallow crater in the sand, using his anterior tibia, pushing the sand back between his middle and hind legs. The food ball is pushed by the male toward the crater and the male then continues digging below the ball while the female is up on top holding on to the ball, 
without participating in the digging. When a certain quantity of sand has accumulated the male turns around and pushes it out using his head and pronotum. Galleries that are dug out this way are oblique to the surface, 13 to $23 \mathrm{~cm}$ long and 3 to $19 \mathrm{~cm}$ deep.

Mating. For the three pairs observed in the field, mating was recorded approximately one hour after rolling started, with the ball buried in the small chamber at the end of the gallery. In the four pairs observed in terrariums, during copulation the female remained firmly attached to the ball with her middle and hind legs, while the male was positioned at an angle of $45^{\circ}$ to the female's horizontal, holding the female firmly with his middle and hind legs and not letting her go for the ca. 30 minutes of copulation. The anterior tibia of the male rest on the posterior pronotum of the female, and he rubs forward and backward very gently, to the base of the elytra. During copulation, the female rotates the ball between her middle and hind legs, and eats from the surface. After releasing the female, the male leaves the chamber and goes to the surface, perhaps providing the opportunity for an intruder male to enter and mate with the female. The female remains in the chamber for two or three days until she has completely eaten the food ball, after which she leaves. Experimentally, we placed a new ball into one of the chambers and the female stayed until she had eaten it as well.

Once the ball has been eaten, the female goes to the surface, to start a new feeding process. At no time during the observations in Repetec did we observe the formation of a brood ball, and this coincides with the state of the ovary in the females we dissected: in the vitellarium there were no mature oocytes, or only oocytes that were beginning to mature. So the observations from Repetec indicate that the balls that are rolled individually can be considered food balls, while those rolled by paired males are prenuptial offerings, given that they are eaten almost exclusively by the female.

Phoretic Transport. On the backs of beetles that were walking along the surface of the sand, those rolling balls, and those buried with a ball, several flies were observed that belong to the genus Ceroptera close to rufitarsis Meigen (Diptera: Sphaeroceridae); these flies stayed on the beetle's bodies, even during abrupt movements.

Kleptoparasitism. In several of the buried balls we found an Aphodiini (Aphodius pruinosus Reitt.), suggesting that this species could be kleptoparasitic on S. acuticollis.

\section{Comparative behaviors in Scarabaeus and Kheper}

In Tables 1 through 3 we give a summary of the known behaviors for different species of Scarabaeus and Kheper during the periods of feeding-gonad maturation, nesting and copulation. Here we analyze the different behavior sequences in an ecological context. 
Table 1. Behavior during feeding and gonad maturation.

\begin{tabular}{lcccc}
\hline & \multicolumn{3}{c}{ Behavior } & \\
\hline Species & 1 & 2 & 3 & 4 \\
S. acuticollis & $\mathrm{X}$ & $\mathrm{X}$ & $14 \%$ & $\mathrm{X}$ \\
S. catenatus & $\mathrm{X}$ & $\mathrm{X}$ & $\mathrm{X}$ \\
S. sacer & $\mathrm{X}$ & $\mathrm{X}$ & $\mathrm{X}$ \\
S. semipunctatus & $87 \%$ & $23 \%$ & $\mathrm{X}$ \\
K. aegyptiorum & $\mathrm{X}$ & $\mathrm{X}$ & \\
K. lamarcki & $\mathrm{X}$ & $\mathrm{X}$ & $\mathrm{O}$ " \\
K. nigroaeneus & $\mathrm{X}$ & $\mathrm{X}$ & $\mathrm{O}$ \\
K. platynotus & $\mathrm{X}$ & $\mathrm{X}$ & \\
K. subaeneus & $\mathrm{X}$ & $\mathrm{X}$ & \\
\hline
\end{tabular}

Explanation of the types of behavior listed in Table 1

In this and the following tables, and $\mathrm{X}$ indicates a behavior that has been specifically mentioned by an author and an $\mathrm{O}$ is used when an author has specifically stated that the behavior does not occur. A blank space indicates that there is no conclusive information. Where it was possible to determine the number of cases out of the total in which a given behavior occurs, this percentage is given.

The feeding-maturation period occurs over one to four weeks after emergence, depending mainly on food availability.

Behavior 1. The male forms and rolls the food balls. A food ball is that which is eaten immediately after being buried. Food balls tend to have a smaller diameter and are not as well made as those used for nesting, even under conditions of intense competition the beetle may roll a dung fragment that is the right size and shape for rolling Behavior 2. Food balls are made and rolled by the female.

Behavior 3. In addition to rolling, as an alternative strategy a gallery may be dug by the male and the female near the source of dung and gradually provisioned (see Discussion).

Behavior 4. Prenuptial offering. The ball is prepared, rolled and buried by the male (the female maintains a passive position) and is then eaten almost exclusively by the female.

"a" Although Tribe (1976) specifically states that there is no rolling by the pair during the feeding period in $K$. nigroaeneus, Edwards and Aschenborn $(1988,1989)$ state that the pair does roll the ball, with the male pushing and the female on top of the ball. These differences could result from the fact that the observations of the latter authors were made at the beginning of the nesting period.

Behaviors during the feeding-maturation period. The first sequence is that followed by Scarabaeus sacer, S. acuticollis and possibly S. semipunctatus, though the information for the latter is incomplete. It occurs under dry or psammophile environmental conditions where dung is scarce. Under these conditions the shaping, rolling and burial of a food ball serves as a prenuptial offering during the feedingmaturation period and is a process carried out by the male, with the female eating the entire ball. The prenuptial offering does not end in nesting. The male goes to the surface after copulation, followed by the female who finishes eating the proffered ball first. During feeding-maturation this process is repeated several times with different males. 
Table 2. Behavior during the nesting period.

\begin{tabular}{|c|c|c|c|c|c|c|}
\hline & & & & & & \\
\hline Species & 1 & 2 & 3 & 4 & 5 & 6 \\
\hline S. bohemani & & $\mathrm{X}$ & & $\mathrm{X}$ & & \\
\hline S. catenatus & $\mathrm{X}$ & $X$ & $\mathrm{X}$ & $\mathrm{X}$ & $1-4$ & $\mathrm{X}$ \\
\hline S. funebris & & & & $\mathrm{X}$ & $1-2$ & \\
\hline S. galenus & & & & $\mathrm{X}$ & 1-4 (usually 1 ) & \\
\hline S. laticollis & $\mathrm{X}$ & & & $\mathrm{X}$ & 2 & \\
\hline S. rugosus & & $\mathrm{X}$ & & $\mathrm{X}$ & & \\
\hline S. sacer & $\mathrm{X}$ & & & & 1 & \\
\hline S. semipunctatus & & $\mathrm{X}$ & & & 1 & \\
\hline K. aegyptiorum & $\mathrm{X}$ & $\mathrm{X}$ & & $\mathrm{X}$ & $1-2$ & $\mathrm{X}$ \\
\hline K. aeratus & & & & $\mathrm{X}$ & 1 & \\
\hline K. clericus & & & & $\mathrm{X}$ & 1 & \\
\hline K. cupreus & & & & $\mathrm{X}$ & $1-2$ & \\
\hline K. lamarcki & & $\mathrm{X}$ & & $\mathrm{X}$ & 2 & \\
\hline K. nigroaeneus & & $\mathrm{X}$ & & $\mathrm{X}$ & 1 & $\mathrm{X}$ \\
\hline K. platynotus & $20 \%$ & $80 \%$ & & $\mathrm{X}$ & $1-4$ & $\mathrm{O}$ \\
\hline K. subaeneus & & $\mathrm{X}$ & & $\mathrm{X}$ & $2-3$ & \\
\hline
\end{tabular}

Explanation of the types of behavior listed in Table 2

Behavior 1. By herself, the female separates dung and rolls the ball that, once buried, will be made into brood balls. Behavior 2. The ball is made by the male and the female, and then rolled by the male (who makes a much greater effort in the process) and also buries it. The process is identical to that of the prenuptial offering but instead of ending in copulation and feeding on the rolled ball, the female makes the ball into one or more nest balls.

Behavior 3. The nest is stocked with dung over successive trips (see Discussion).

Behavior 4. Post-oviposition care. The female remains in the nest.

Behavior 5. Number of brood balls per nest.

Behavior 6. With variable frequency, a prenuptial offering is made at the beginning of the nesting process.

The contribution of the male in the form of the prenuptial offering during gonad maturation in the female has clear ecological significance. In places where dung is scarce the offering allows the oocytes to mature. The prenuptial offering is a behavior that in harsh ecological conditions ensures that the highest number of females reach gonad maturity and survive until nesting (paternal effort sensu Trivers 1972). However, the insemination by the males of as many females as possible during this period could later give their sperm the opportunity to fertilize the females during the nesting stage. This represents an important advantage in the context of sperm competition where the sperm of different males compete to fertilize the ova of the female (Parker 1970). 
Table 3. Copulation.

\begin{tabular}{|c|c|c|c|c|c|}
\hline & & & havi & & \\
\hline Species & 1 & 2 & 3 & 4 & 5 \\
\hline S. bohemani & $\mathrm{X}$ & $\mathrm{X}$ & & & $\mathrm{X}$ \\
\hline S. catenatus & $\mathrm{X}$ & & & $\mathrm{X}$ & $\mathrm{X}$ \\
\hline S. rugosus & $\mathrm{X}$ & $\mathrm{X}$ & & & $\mathrm{X}$ \\
\hline S. sacer & & $\mathrm{X}$ & & $\mathrm{X}$ & \\
\hline K. aegyptiorum & $\mathrm{X}$ & & & $\mathrm{X}$ & $\mathrm{X}$ \\
\hline K. lamarcki & $\mathrm{X}$ & & & & $\mathrm{X}$ \\
\hline K. nigroaeneus & $\mathrm{X}$ & & & $\mathrm{X}$ & $\mathrm{X}$ \\
\hline K. platynotus & $\mathrm{X}$ & $\mathrm{X}$ & $\mathrm{X}$ & $\mathrm{O}$ & $\mathrm{X}$ \\
\hline K. subaeneus & $\mathrm{X}$ & & & & $\mathrm{X}$ \\
\hline
\end{tabular}

Explanation of the types of behavior listed in Table 3

Behavior 1. The male attracts the female by emitting pheromones.

Behavior 2. Copulation occurs during the joint (male-female) activities of making and rolling the ball. The male is present until the ball is buried.

Behavior 3. The male forces copulation on a female that is making or rolling a ball. Immediately after copulation the male leaves.

Behavior 4. After rolling the prenuptial offering, copulation occurs on the buried ball.

Behavior 5. Copulation occurs on the buried ball before nest ball preparation is begun.

A process similar to the shaping and rolling of the ball for a prenuptial offering occurs over a different time frame in several species ( $S$. catenatus, K. aegyptiorum and $K$. nigroaeneus (Tables 1 and 2). With greater or lesser frequency they offer a nuptial gift at the beginning of the nesting period, but the ball is not necessarily completely eaten by the female and the rest is transformed into brood balls. Thus it is a behavior that forms part of the nesting cycle.

During the feeding-maturation period and the transition to nesting, whether the ball offered by the male becomes a prenuptial ball appears to depend on the degree of ovary maturity in the female. In S. acuticollis, in the desert, the lack of dung prolongs the maturation period. Where dung is abundant, ovary maturation is a more rapid process and there is overlap between the feeding-maturation and nesting stages.

Behaviors during the process of nesting. In the type of behavior sequence exhibited by $S$. sacer, nesting, i.e. the shaping, rolling and burying of a ball and its transformation into a brood ball is done by the female alone. Only in Scarabaeus laticollis has behavior similar to that of $S$. sacer been reported (although it is possible that it also occurs in $S$. semipunctatus). In other species a female will occasionally nest alone, but it is most common (see Table 2) for the process to be carried out by the pair, with copulation before the elaboration of the brood ball or brood balls. We do not dismiss the possibility that in S. sacer and S. laticollis the nesting process is also carried out 
by the pair. Further studies of these species should focus on whether during the nesting process pairs that nest together are formed.

The role of the male in nesting. All authors since Tribe (1976), who have worked with African species of Scarabaeus and Kheper have mentioned the emission of pheromones by the male as a mechanism of attracting the female. The pheromones secreted from the pores of the first abdominal segments are dispersed by successive movements of the hind legs. This might be done over the food source, in association with a ball that is being rolled or buried, or even on the remains of food. Where dung is abundant, pheromone emission by African species once again highlights the priority in these species of copulation over offering food, in contrast to what occurs in $S$. sacer. Inseminating the highest number of females possible (mating effort) is more important to the male than helping female gonad maturation, a process that occurs even without male intervention. In the nesting process of practically all Scarabaeinae there are different degrees of male-female cooperation (see exceptions in López-Alarcón et al., 2009). In terms of intraspecific competition, the greater or lesser participation of the male determines the differences in the speed with which the food is relocated for nesting. However, in all the species of Scarabaeinae (including Scarabaeus and Kheper) for which this has been studied, the female is capable of nesting alone. This suggests that the sperm of the males with which the female has copulated during the feeding-maturation period, or during the nesting period, continues to be viable until nesting.

In general terms, the degree of participation of the male in the nesting process differs in the two large branches of behavior that identify food relocation in Scarabaeinae: rollers and tunnelers. Male rollers play an important role in supplying the nest by transporting the ball from the food source. Male tunnelers play a secondary role and provisioning is achieved over several trips between the food source and the subterranean gallery where the female will nest. For S. catenatus, Sato $(1997,1998)$ has described two strategies for provisioning the feeding gallery and the nest. In the first, the beetle makes a ball or separates a piece of dung, rolls it a certain distance and buries it by digging out the soil from under the ball. During this provisioning by rolling, the male takes the initiative and does most of the work. In the second strategy, the beetle excavates a tunnel beside or near the dung pat and, piece by piece, over several trips provisions the gallery. The male has a secondary role, as he is less active than the female in excavating and provisioning the tunnel. In nesting, the two strategies are followed cooperatively by the male-female pair, or by just the female when she nests without a male. In all cases the next step is the elaboration of brood balls by the female and the postoviposition care she provides.

According to Sato (1998) the participation of the male in nesting in either of the two strategies does not increase the reproductive success of the female as measured by the number and size of the brood balls. The male functions as a guardian (mate 
guarding) against other males. Prior to the studies done by Sato $(1997,1998)$ on $S$. catenatus, the existence of two nest provisioning strategies had been documented for another African Scarabaeini (Tribe 1976), the only species of the genus Pachylomera Bertoloni: P. femoralis (Kirby).

Attraction and sexual selection. The shaping and rolling of a prenuptial ball by the male is a mechanism for attracting the female in species in which it appears that the male does not emit pheromones such as $S$. sacer, $S$. acuticollis and $S$. semipunctatus. Although with less frequency, the male joins the female who has begun to shape a ball or is rolling one. The female shows a certain degree of sexual selection by being more accessible to cooperative males than to those that try to force copulation. The tendency to favor cooperative males is associated with the reproductive success of the female. This success does not depend on the number of copulations, but rather on the female's capacity to obtain and prepare the resources necessary to make the brood balls. In Canthon c. cyanellus LeConte it has been shown experimentally that the balls rolled by sexually mature males are more attractive than control balls not rolled by males, and more attractive than balls rolled by the females themselves owing, presumably, to the impregnation of the balls by the males with chemical attractants produced in their sternal glands (Favila 1988, 2001). It is possible that the food balls rolled by male Scarabaeus and Kheper are impregnated with compounds produced in their abdominal glands and that these compounds serve to attract and keep the females close.

The most important intrasexual selection occurs between males and is the relationship between fight success and copulations achieved. This process of sexual selection is very active both during initial copulations during the feeding-maturation period, and during nesting. In K. platynotus during fights the owner of the ball is successful in $73 \%$ of the male-male confrontations and in $81 \%$ of the female-female fights (Sato \& Hiramatsu, 1993). In this diurnal species in $92 \%$ of the fights, the largest beetle won (owner or intruder). In the crepuscular species, Scarabaeus laevistriatus, the internal temperature of the species is more important for ensuring victory than size (Heinrich and Bartholomew, 1979). In Canthon c. cyanellus the factors that affect male-male and female-female combat have been experimentally studied (Chamorro-Florescano \& Favila, 2008, 2009; Chamorro-Florescano, 2009), and they are: body size (larger beetles are more successful); reproductive state (previously mated individuals are more successful, even when the intruder is larger if said intruder is sexually inexperienced); and whether the beetle is the owner or the intruder (owners are more successful). Further studies are necessary to clarify how these and other extrinsic and intrinsic asymmetries influence intraspecific contests in other dung roller beetle species (Chamorro-Florescano \& Favila 2008).

Mating. For all species of Kheper and Scarabaeus, except $K$. platynotus, mating occurs on the dung pile, during the process of shaping the dung and rolling the ball, 
or once the ball is buried (see Table 3). That is, to some extent mating is associated with a process of male-female cooperation. It is worth noting that in all the species of Scarabaeus and Kheper studied, there are one or several matings during the feedingmaturation period. Observations of several species of each genus suggest that by the time the nesting period begins the female's spermatheca is loaded with sperm. Mating immediately preceding nesting (and this occurs in all species with the exception, to our knowledge, of those exhibiting the $S$. sacer behavior type) must be related to sperm priority in fertilization. There are quantitative data on the importance of prior copulation in Canthon c. cyanellus in which $94 \%$ of the females that nest have in their spermatheca viable sperm from prior copulation with other males (Favila et al., 2005). Although copulation during the feeding-maturation period allows a lone female to nest, this copulation only ensures the fertilization of the first five to seven brood balls constructed (in C. c. cyanellus, multiple nest), which indicates a limited viability of the sperm (Favila 2001). In the subsocial species of Scarabaeus and Kheper, the female builds a single nest (with a maximum of four brood balls, Table 2) per reproductive season, so a single mating per season is sufficient; however, given that there are prior copulations during the feeding-maturation period, it is possible that the males that nest with a female face the risk of sperm competition.

Timing and frequency of matings and sperm priority. Brown et al. (1997) state that copulation can occur via one of the three following mechanisms: 1) persuasion, which includes the offer of an incentive; 2) coercion, which implies controlling the female; and 3) by force, an action not accepted by the female. The males of different species of Scarabaeus and Kheper use the three mechanisms at different times.

In Scarabaeus and Kheper persuasion occurs via the offer of a prenuptial gift during the feeding-maturation period or at the beginning of nesting, as a way of facilitating access to the female by gifting her with a large amount of food. Coercion combines supporting the female with limiting her freedom. The cooperative behavior of males during the shaping, rolling and burying of the ball, and by guarding the nest (when this behavior occurs) represents an important contribution to the processes of nesting, but at the same time monopolizes the female, by driving off other males in combat. In K. platynotus (Sato \& Hiramatsu 1993) the male has two mating strategies: 1) forced copulation ( $21 \%$ of the observed copulations), which is resisted with varying degrees of vigor by the female; once the male has mated he abandons the female; 2) copulation as it occurs in other species during the cooperative activities mentioned above. The first strategy is clearly a mating effort on the part of the male; an effort which, though not as obvious as in K. platynotus, does occur with a certain frequency in many species of Scarabaeus and Kheper. This strategy has not been reported for species that follow the type of behavior exhibited by $S$. sacer. In the latter species, copulation, even during the feeding-maturation period, is always associated with cooperative behavior (prenuptial offering). In C. c. cyanellus the persuasion 
mechanism includes a ball rolled by the male, but coercion occurs when making a multiple nest, during which the male denies other males access to the female and protects his parental investment by copulating with the female each time she goes to make another brood ball (Favila et al. 2005, Chamorro-Florescano \& Favila 2009).

Sperm competition and paternity assurance. Multiple copulations with different males during the feeding-maturation and nesting periods create the problem of sperm priority. This conflict is particularly intense between the ejaculate of the first copulations (from different males) and those from repeated copulation during the nesting period; the latter with a cooperative male who monopolizes the female and drives off other males.

Repeated copulation can favor the sperm priority of the last male to copulate with a female. After each copulation the sperm disintegrate in the bursa copulatrix and after a few hours are stored in the spermatheca (observed in Canthon c. cyanellus and other spp. of Canthon, see Martínez \& Cruz 1990; Cruz 1993). The spermatheca is Cshaped and at one end connects to the ductus receptaculi. A powerful muscle joins the two branches of the $\mathrm{C}$. When extended, the spermatheca is thought to pulls inwards and on contraction the muscle is believed to expels the sperm. Halffter (1997) proposed that when the sperm of a new copulation are pulled inwards this pushes the sperm from previous copulations deeper into the closed branch of the spermatheca. When the spermatheca contracts the sperm from the last copulation are the first to leave via the oviduct. This mechanism would give priority to the sperm of the last male to copulate with the female. Experimental studies on Canthon c. cyanellus, using a genetic marker have provided a quantitative estimate of the relative reproductive success of the different copulations (Favila et al. 2005). The paternity of a male that copulates with a female that has mated previously with other males, but that does not continue the process of nesting is $50 \%$, suggesting strong sperm competition. When the male does participate in nesting, and copulates with the female several times before making the brood balls and during their preparation, paternity is high $(>80 \%)$. Favila et al. (2005), suggest that in Canthon cyanellus cyanellus, repeated mating during nesting, especially before brood ball elaboration, gives the sperm of the last male a numerical advantage, reducing cuckoldry and increasing its paternity significantly. Furthermore, the presence of the male in the nest during the elaboration of the brood balls by the female has been interpreted by Favila et al. (2005), as guarding behavior, and prevents other males from mating with the female. Repeated copulation while the brood balls are being made has also been observed in Scarabaeus and Kheper (Table 3; Tribe 1976), suggesting that cooperative males increase the priority of their sperm. In addition, staying in the nest until brood ball preparation and oviposition have concluded prevents the intrusion of other males; and the way in which the ejaculate from successive copulations is stored in the spermatheca allows the female to favor the last male with whom she copulated. 
Cephalodesmius (see Monteith \& Storey 1981), another genus of Canthonini, has a peculiar way of handling food. The species of this Australian genus neither make nor roll balls of food, thus eliminating interactions at the food source and reducing the risk of intrasexual competition to very low levels. Interestingly, the Cephalodesmius couple is monogamous during their long nesting period. This suggests that the risks of competition are minimal, in contrast to what occurs in Scarabaeus, Kheper and Canthon, whose use of ephemeral resources has encouraged both precopulatory and postcopulatory intraspecific competition. In Cephalodesmius however, there are several copulations during nesting which suggests that this may play a role in the maturation of the female, though we cannot dismiss the possibility of sperm conflict with other males with whom the female has mated previously or the possibility that this is a vestigial behavior resulting from phylogenetic inertia.

Parental care. In all the species of Kheper studied and most of the Scarabaeus spp. (except those with sacer type behavior, see Table 2) the females give postoviposition care to the brood balls. Although all authors (including Halffter 1997) cite Sato \& Imanori (1986) as the first publication of this behavior in these genera, this is inaccurate. A careful reading of J.H. Fabre (see the Definitive Edition of Souvenirs Entomologiques 1925) reveals that, for Scarabaeus laticollis Linnaeus, this author had observed the female to roll and bury a ball that in the subterranean nest was transformed over the course of three or four weeks into two piriform brood balls that were then prepared and taken care of. The observations of Fabre leave no room for doubt as he compared the behavior of $S$. laticollis with that of $S$. sacer.

Subsocial behavior in Kheper and Scarabaeus implies that after the last copulation (see Table 3) the male abandons the female, while the female stays in the nest and transforms the rolled food ball into one to four brood balls that she cares for until her progeny emerges. In some species, before making the brood balls, the female may partially eat the rolled ball. It is in these cases that the nuptial offering forms an immediate part of the nesting process (see Table 2).

In all of the species of Scarabaeus and Kheper that exhibit subsocial care, the fertility per female/season is extraordinarily low (1 to 4 eggs). Even though the male makes the biggest investment in preparing and rolling the ball, and by fighting to protect his property, it is the female who spends months taking care of the nest and takes investment in offspring to its maximum expression.

\section{CONCLUSIONS}

According to our analysis the role of the male and the male-female interactions in Scarabaeus and Kheper fall into two different behavioral sequences. In the first, the male rolls a ball or a food fragment as a prenuptial offering for the female during the feeding-maturation period; at this stage copulation may occur once the food has been buried, but it does not end in nesting. At this stage, the function of copulation 
is to bring the female to sexual maturity. This sequence of behaviors occurs under extreme ecological conditions, such as in deserts, where dung is an extremely limited resource. In the second sequence, the food that is rolled by the male and which the female joins, is used by the female to prepare brood ball(s) in the nest. However, females can nest by themselves, in the absence of males, possibly using sperm stored in their spermathecae from the feeding-maturation period, or during the nesting period. This second sequence occurs in savannas and other ecosystems where there is strong competition for food, even though it is abundant. Once the brood ball is in place, care of the progeny is common in the species of Scarabaeus and Kheper which follow the second behavioral sequence. In all cases, it is the female that cares for the offspring or the brood balls (see Tables $1-3$ ). These differences, as well as the fact that $S$. catenatus stocks the nest in two different ways, are clearly associated with different ecological conditions, particularly dung availability.

ACKNOWLEDGMENTS. G. and V. Halffter visited Repetec and other sites in Turkmenistan under the auspices of cooperation agreements between Mexico and Soviet Union's UNESCO-MAB (Man and the Biosphere) committees. This exceptional trip received every conceivable type of support and was organized by one of the great figures in zoology in the 20th century, Vadimir Sokolov (1928-1998), academician, President of the MAB Soviet Union Committee and Director of the Severtsov Institute of Ecology and Evolution. In Repetec both authors were accompanied by Dr. Lev Medveder of the Severtsov Institute. The Ceroptera were identified by Dr. Ke Chung Kim of Pennsylvania State University. Matthias Rös of the Instituto de Ecología, A.C. translated the studies of Heymons and von Lengerken from the originals in German and made possible a new review of these fundamentally important texts possible. Bianca Delfosse translated this article from the original in Spanish. We extend our sincerest gratitude to all of them.

\section{LITERATURE CITED}

Brown, W. D., B. J. Crespi \& J. C. Choe. 1997. Sexual conflict and the evolution of mating systems. In J.C. Choe \& B.J. Crespi (Eds.). The Evolution of Mating Systems in Insects and Arachnids, pp. 352-377. Cambridge University Press, Cambridge, UK.

Chamorro-Florescano, I. 2009. Asimetrías en la capacidad de defender el recurso y su influencia en el éxito reproductivo del escarabajo rodador Canthon cyanellus cyanellus LeConte (Scarabaeidae, Scarabaeinae). Ph.D. Dissertation. 109 pp. Instituto de Ecología, A.C., Xalapa, México.

Chamorro-Florescano, I. \& M. E. Favila. 2008. Male reproductive status affects contest outcome during nidification in Canthon cyanellus cyanellus LeConte (Coleoptera: Scarabaeidae). Behavior, 145: 1811-1821.

Chamorro-Florescano, I. \& M. E. Favila. 2009. The reproductive status of both sexes affects the frequency of mating and the reproductive success of males in the ball roller beetle Canthon cyanellus cyanellus (Coleoptera: Scarabaeidae). Behavior, 146: 1499-1512.

Cruz, M. 1993. Actividad reproductora de los machos de Canthon indigaceus chevrolati Harold y Canthon cyanellus cyanellus LeConte y su influencia en el comportamiento reproductor de las hembras (Insecta, Coleoptera, Scarabaeinae). M.Sc. Thesis. 129 pp. Escuela Nacional de Ciencias Biológicas, IPN, México, D.F. 
Edwards, P. B. 1988. Field ecology of a brood-caring dung beetle Kheper nigroaeneus - habitat predictability and life history strategy. Oecologia, 75: 527-534.

Edwards, P. B. \& H. H. Aschenborn. 1988. Male reproductive behavior of the African ball-rolling dung beetle, Kheper nigroaeneus (Coleoptera: Scarabaeidae). The Coleopterist Bulletin, 42: 17-27.

Edwards, P. B. \& H. H. Aschenborn. 1989. Maternal care of a single offspring in the dung beetle Kheper nigroaeneus: the consequences of extreme parental investment. Journal of Natural History, 23: 17-27.

Fabre, J. H. 1897. Souvenirs Entomologiques, $5^{\text {th }}$ series. Delagrave, Paris.

Fabre, J. H. 1925. Souvenirs Entomologiques (Cinquième Série). Edition Définitive Illustrée. 384 pp. Librairie Delagrave, Paris.

Favila, M. E. 1988. Comportamiento durante el periodo de maduración gonádica en un escarabajo rodador (Coleoptera: Scarabaeidae: Scarabaeinae). Folia Entomológica Mexicana, 76: 55-64.

Favila, M. E. 2001. Historia de vida y comportamiento de un escarabajo necrófago: Canthon cyanellus cyanellus LeConte (Coleoptera: Scarabaeinae). Folia Entomológica Mexicana, 40: 245-278.

Favila, M. E., J. Nolasco-Soto, I. Chamorro-Florescano \& M. Equihua. 2005. Sperm competition and evidence of sperm fertilization patterns in the carrion ball-roller Canthon cyanellus cyanellus LeConte (Scarabaeidae: Scarabaeinae). Behavioral Ecology and Sociobiology, 59: 38-43.

Favila, M. E., J. Nolasco-Soto, M. Ortiz-Domínguez. 2004. Visible genetic markers for the color of external body structures and eyes in the carrion scarab Canthon cyanellus cyanellus LeConte (Coleoptera: Scarabaeidae). Annals of Entomological Society of America, 97: 1045-1049.

Favila, M. E., G. Ruiz-Lizarraga, J. Nolasco-Soto. 2000. Inheritance of a red cuticular color mutation in the scarab beetle Canthon cyanellus cyanellus LeConte (Coleoptera: Scarabaeidae). The Coleopterists Bulletin, 54: 541-545.

Goggio, E. 1926. Studii sulla vita dell'Ateuchus semipunctatus Fabricius. Archivio Zoologico Italiano, 11: 1-44.

Halffter, G. 1997. Subsocial behavior in Scarabaeinae beetles. In J.C. Choe \& B.J. Crespi (Eds.). The Evolution of Mating Systems in Insects and Arachnids, pp. 237-259. Cambridge University Press, Cambridge, UK.

Halffter, G. \& W. D. Edmonds. 1982. The Nesting Behavior of Dung Beetles (Scarabaeinae). An Ecological and Evolutive Approach. 176 pp. 143 figs. Instituto de Ecología, A.C., México, D.F.

Halffter, G. \& E. G. Matthews. 1966. The Natural History of Dung Beetles of the Subfamily Scarabaeinae (Coleoptera, Scarabaeidae). Folia Entomologica Mexicana, 12-14: 1-312.

Harrison, J. G., C. H. Scholtz \& S. L. Chown. 2003. A revision of the endemic south-western African dung beetle subgenus Scarabaeus (Pachysoma) MacLeay, including notes on other flightless Scarabaeini (Scarabaeidae: Scarabaeinae) Journal of Natural History, 37: 305-355.

Heinrich, B. \& G. A. Bartholomew. 1979. The ecology of the African dung beetle. Scientific American, 241: 118-126.

Heymons, R. \& H. von Lengerken. 1929. Biologische Untersuchungen an Coprophagen Lamellicornien, I. Nahrungsewerb und Fortpflanzungsbiologie der Gattung Scarabaeus L. Zeitschrift für Morphologie und Öekologie der Tiere, 14: 531-613.

Lengerken, H. von. 1951. Der Pillendreher (Scarabaeus). 53 pp. Akademische Verlags-gesellschafr Geest \& Portig K.-G. Leipzig.

López-Alarcón, D., G. Halffter \& F. Z. Vaz-de-Mello. 2009. Nesting behavior in Trichillum Harold, 1868 and related genera (Coleoptera: Scarabaeidae: Scarabaeinae: Ateuchini: Scatimina): A primitive process or a loss of nidification? The Coleopterists Bulletin, 63: 289-297.

Martínez, I. \& M. Cruz. 1990. Cópula, función ovárica y nidificación en dos especies del género Canthon Hoffmannsegg (Coleoptera: Scarabaeidae). Elytron, 4: 161-169. 
Monteith, G. H. \& R. I. Storey. 1981. The biology of Cephalodesmius, a genus of dung beetles which synthesizes "dung" from plant material (Coleoptera: Scarabaeidae: Scarabaeinae). Memoirs of the Queensland Museum, 20: 253-271.

Palestrini, C., E. Barbero \& M. Zunino. 1992. The reproductive behaviour of Kheper aeratus (Gerstaecker) and the evolution of subsociality in Scarabaeidae (Coleoptera). Ethology, Ecology and Evolution, 2: 27-31.

Parker, G. A. 1970. Sperm competition and its evolutionary consequences in the insects. Biological Reviews, 45: 525-567.

Sato, H. 1997. Two nesting behaviors and life history of a subsocial African dung-rolling beetle, Scarabaeus catenatus (Coleoptera: Scarabaeidae). Journal of Natural History, 31: 457-469.

Sato, H. 1998. Pay offs of the two alternative nesting tactics in the African dung beetle, Scarabaeus catenatus. Ecological Entomology, 23: 62-67.

Sato, H. 1998. Male participation in nest building in the dung beetle Scarabaeus catenatus (Coleoptera: Scarabaeidae): Mating effort versus paternal effort. Journal of Insect Behavior, 11: 833-843.

Sato, H. \& K. Hiramatsu. 1993. Mating behavior and sexual selection in the African ball-rolling scarab Kheper platynotus (Bates) (Coleoptera: Scarabaeidae). Journal of Natural History, 27: 657-668.

Sato, H. \& M. Imamori. 1986. Nidification of an African ball-rolling scarab, Scarabaeus platynotus Bates (Coleoptera: Scarabaeidae). Kontyû, 54: 203-207.

Sato, H. \& M. Imamori. 1986. Production of two brood pears from one dung ball in an African ballroller, Scarabaeus aegyptiorum (Coleoptera: Scarabaeidae). Kontyû, 54: 381-385.

Sato, H. \& M. Imamori. 1987. Nesting behaviour of a subsocial African ball-roller Kheper platynotus (Coleoptera: Scarabaeidae. Ecological Entomology, 12: 415-425.

Sato, H. \& M. Imamori. 1988. Further observations on the nesting behavior of a subsocial ball-rolling scarab, Kheper aegyptiorum. Kontyû, 56: 873-878.

Scholtz, C. H. 1989. Unique foraging behavior in Pachysoma (= Scarabaeus) striatum Castelnau (Coleoptera: Scarabaeidae): an adaptation to arid conditions? Journal of Arid Environments, 1: 117128.

Scholtz, C. H., J. G. Harrison \& V. V. Grebennikov. 2004. Dung beetle (Scarabaeus (Pachysoma)) biology and immature stages: reversal to ancestral states under desert conditions (Coleoptera: Scarabaeidae)? Biological Journal of the Linnean Society, 83: 453-460.

Tribe, G. D. 1976. The ecology and ethology of ball-rolling dung beetles (Coleoptera: Scarabaeidae). M.Sc. Thesis. Faculty of Agriculture, University of Natal, South Africa.

Trivers, R. L. 1972. Parental investment and sexual selection. In: B. Campbell (Ed.). Sexual Selection and the Descent of Man. Pp. 136-179. Aldine, Chicago. 